\title{
CHALLENGES AND SOLUTIONS IN MAINTAINING INDONESIAN GENERATION Z NATIONALISM IN THE DIGITALIZATION ERA
}

\section{Timothy Adamentha Tarigan ${ }^{1}$, Fredrick Liui ${ }^{2}$, Muhammad Hanif ${ }^{3}$, Moses Glorino Rumambo Pandin ${ }^{4}$}

${ }^{1,2}$ Faculty of Science and Technology, Airlangga University Surabaya

${ }^{3}$ Faculty of Advance \& Multidisciplinary Technology, Airlangga University Surabaya

${ }^{4}$ Faculty of Humanities, Airlangga University Surabaya

Email: timothy.adamentha.tarigan-2021@fst.unair.ac.id, muhammad.hanif-

2021@ftmm.unair.ac.id, fredrick.liui-2021@fst.unair.ac.id, and

moses.glorino@fib.unair.ac.id

\begin{abstract}
Abstrak
Saat ini Indonesia sedang menghadapi pandemi yang membawa kita pada transformasi digital yang cepat, yang membawa kita ke tengah era digitalisasi. Salah satu generasi yang menyerap efeknya adalah Generasi Z. Meski Generasi Z menguasai teknologi lebih baik dari generasi lainnya, namun rasa nasionalisme Generasi Z tidak bisa luntur karena nasionalisme diperlukan bagi suatu bangsa. Metode studi literatur yang digunakan dalam penulisan ini, dimana penulis mengumpulkan bahan-bahan literatur berdasarkan beberapa kata kunci di Google Scholar. Secara umum tantangan yang dihadapi Generasi Z berupa sifat buruk Generasi Z, penyalahgunaan teknologi, budaya asing yang tidak terfilter, serta pengaruh buruk media sosial \& dunia maya. Pancasila sebagai dasar bangsa memegang peranan utama dalam penyelesaian masalah ini karena di dalamnya terkandung nilai-nilai kehidupan dan jati diri bangsa. Pendidikan karakter juga diperlukan karena memegang banyak aspek penting untuk membangkitkan rasa nasionalisme. Pendekatan unik lainnya juga cukup penting, seperti implementasi etnomatematika \& ekstrakurikuler pramuka. Kami kekurangan solusi untuk memperbaiki masalah ini. Cara yang lebih inovatif perlu ditemukan dan diterapkan untuk menjaga rasa nasionalisme pada Generasi Z.
\end{abstract}

Kata kunci: tantangan nasionalisme, generasi Z, era digital

\section{Abstract}

Nowadays, Indonesia is facing a pandemic that brought us to a rapid digital transformation, which brings us to the middle of the digitalization era. One of the generations who absorb the effect of this is Generation Z. Although Generation $Z$ mastered technology better than other generations, Generation Z's sense of nationalism can't fade because nationalism is necessary for a nation. The literature study method is used in this paper, where the writer collected literature materials based on some keywords in Google Scholar. Generally, challenges that Generation Z's facing is in the form of bad characteristics of Generation Z, technology abuse, unfiltered foreign culture, and bad influence of social media \& virtual world. Pancasila as the nation's fundamental holds the main role for this

Copyright holder: Timothy Adamentha Tarigan, Fredrick Liui, Muhammad Hanif, Moses Glorino Rumambo Pandin (2022)

DOI : https://doi.org/10.54543/fusion.v2i02.160

Published by

: Rifa Institute 
problem's solution since it contains values of life and national identity. Character education is also necessary since it holds many important aspects to stir up the sense of nationalism. Other unique approaches are also quite important, such as ethnomathematics implementation \& scout extracurricular. We are lacking in solutions to fix this issue. More innovative ways need to be discovered and implemented to maintain the sense of nationalism in Generation $\mathrm{Z}$.

Keywords: nationalism challenges, generation $Z$, digital era

Submitted: 03-01-2022

Accepted: 25-01-2022

Publish: 20-02-2022

\section{Introductions}

The covid-19 pandemic has hit hard on all aspects of life, from health to socio-economic aspects. Covid-19 pandemic has forced us to keep our distance and carry out activities from home. However, this pandemic does not always bring bad news to the world. Indirectly, Covid19 has ushered us further into the era of digitalization (Hayati, 2021). Many community activities are carried out at home resulting in a shift in consumption patterns and community needs (Lee et all., 2021). This phenomenon leads to the acceleration of digital transformation. As a result, humans enter the digitalization era more quickly.

The digitalization era itself is an era where all kinds of information can be easily and quickly obtained, and in the process, it is implemented through various existing digital technologies (Degtyarefa et all., 2021). Digital technology has become a tool that makes human life easier, both in carrying out tasks and work. The role of technology influences life, humans, especially Generation Z.

In Indonesia, Generation $\mathrm{Z}$ is one of the most dominant generations in 2020. People who were born from 1995 to 2010 belong to Generation Z (BPS, 2021). Gen Z is shaped by the rapid changes \& developments in technology, especially digital technology (Jenkins, 2017). The need for this technology can be likened to the human need to breathe. Gen $\mathrm{Z}$ also has characters that are more diverse, global in nature, and able to form individuals who act as agents of change. Gen $\mathrm{Z}$ is also open to accepting various views and mindsets (Seemiller et all., 2016). However, this has the potential to make someone unstable and have a changing self-identity.

The instability of self-identity possessed by Gen $\mathrm{Z}$ has the potential to cause young people to be disoriented towards individuals who deviate from national identity. National identity is closely related to a person's sense of nationalism (Jensen, 2016). This situation proves that there is a relationship between the impact of the digitalization era and nationalism. The digital transformation that is growing rapidly is very possible for a person's sense of nationalism to decrease.

The real evidence that can be seen today is hoax news. Gen $\mathrm{Z}$ is more susceptible to exposure to hoaxes/fake news as a result of the ease of obtaining information (Pratiwi, 2019). The relationship between hoax news and nationalism can be in the form of a change in Gen Z's view of various existing problems, such as unity and integrity. Wrong views encourage Gen Z to judge a problem from that side only, it has the potential to reduce one's sense of nationalism (Pratiwi, 2019). In addition, another most visible impact is the free entry of foreign cultures into a country (Starrs, 2014). If these conditions are left unchecked without any control from each party, the influence of foreign cultures can reduce the sense of nationalism of Gen Z.

Based on the problems described in the background, the main focus of this research is to contribute through an analysis of the importance of maintaining nationalism in the digitalization era. Besides that, this research analyses challenges that exist. As a result, Generation $\mathrm{Z}$ became more introspective about the degradation of the sense of nationalism. In 
addition to this, this article is certainly useful for teachers or educators on Citizenship Education subjects in providing solutions to the problems faced by Generation $\mathrm{Z}$ in maintaining a sense of nationalism, especially in the era of digitalization.

\section{Methodology}

The literature study method is a research procedure method that will be used in this Citizenship research project. A literature study has an understanding in the form of orientation, concept, or framework for classifying \& analyzing the facts that have been collected in conducting research (Tuckman et all, 2012). Reference sources \& data used in the literature study must be relevant and up-to-date by library references (Ajayi, 2017). A literature study was conducted to find and gather information as a theoretical basis to support problem-solving from Citizenship research. The collection of references $\&$ data to be used in the literature study was taken from Google Scholar with the keywords "Nationalism", "Generation Z", and "Era of digitization". References \& data collected consist of books, scientific articles, and journals relevant to the Civics project title "Generation Z Awareness in Indonesia in Maintaining a Sense of Nationalism in the Era of Digitalization". The research will be carried out using qualitative data analysis methods, namely by reviewing data obtained from literature studies (Ezzy, 2013). The data obtained will be interpreted and concluded descriptively according to the issues raised regarding nationalism.

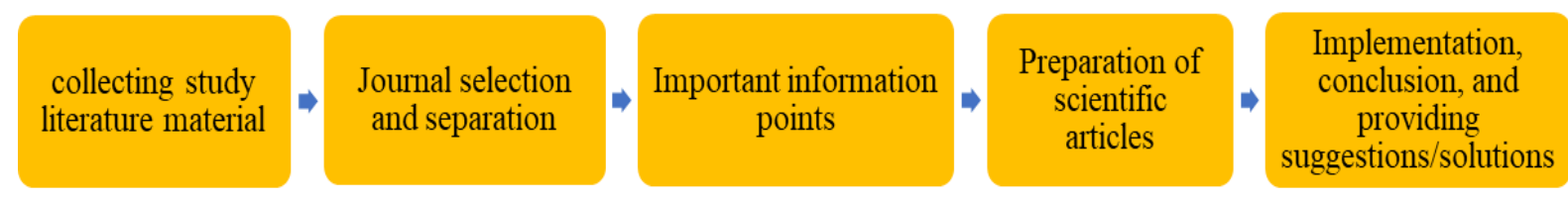

The first stage is collecting literature study materials in the form of journals and articles related to the title, collecting 30 journals and articles related to the title using articles published in 2019, 2020, and 2021 and there are 5 written references from the Airlangga University academic community. Then the second is the selection and separation of journals that will be used as references for scientific articles and the integration of journals and other articles that have been read and studied. Third, important information points were written so that the main ideas/thoughts become clearer. Fourth, the preparation of scientific articles based on the information points \& the specified format. Fifth, conducting discussions, conclusions, as well as presenting suggestions/solutions based on scientific articles made.

\section{Results}

Table 1. Research Literature on Generation Z Awareness in Indonesia in Maintaining a Sense of Nationalism in the Era of Digitalization

\begin{tabular}{llll}
\hline $\begin{array}{c}\text { Author and } \\
\text { Year of } \\
\text { Publication }\end{array}$ & $\begin{array}{c}\text { Research } \\
\text { Methods }\end{array}$ & $\begin{array}{c}\text { Factors Related to } \\
\text { Sense of Nationalism }\end{array}$ & $\begin{array}{l}\text { Research Results and/or } \\
\text { Conclusion Regarding } \\
\text { Generation Z }\end{array}$ \\
\hline $\begin{array}{l}\text { Hermino, A. } \\
\text { \& Arifin, I., }\end{array}$ & $\begin{array}{l}\text { Constant } \\
\text { qualitative \& } \\
\text { comparative } \\
\text { research } \\
\text { methods }\end{array}$ & $\begin{array}{l}\text { Socio-economic } \\
\text { conditions, the } \\
\text { influence of the } \\
\text { internet, and traditional } \\
\text { customs are the main } \\
\text { focus factors for }\end{array}$ & $\begin{array}{l}\text { Nationalism is one of the most } \\
\text { important characters in } \\
\text { developing the character of } \\
\text { high school youth. This } \\
\text { character development is } \\
\text { useful in the process of }\end{array}$ \\
\hline
\end{tabular}




\begin{tabular}{|c|c|c|c|}
\hline & & $\begin{array}{l}\text { influencing the strong } \\
\text { sense of nationalism. }\end{array}$ & maturity. \\
\hline $\begin{array}{l}\text { Lestari, } \\
\text { E.Y., Janah, } \\
\text { M., } \\
\text { Wardani, } \\
\text { P.K.,2019 }\end{array}$ & $\begin{array}{l}\text { Qualitative } \\
\text { research } \\
\text { methods through } \\
\text { analysis of } \\
\text { literature studies }\end{array}$ & $\begin{array}{l}\text { Factors that cause the } \\
\text { waning of Nationalism } \\
\text { can be in the form of } \\
\text { internal factors } \\
\text { (Indonesia's lagging } \\
\text { behind other nations) } \\
\text { and external factors } \\
\text { (globalization and the } \\
\text { presence of other } \\
\text { understandings). }\end{array}$ & $\begin{array}{l}\text { Awareness of nationalism in } \\
\text { the younger generation can be } \\
\text { increased through the role of } \\
\text { family, education, and } \\
\text { government. In addition, this } \\
\text { awareness can be increased } \\
\text { through concrete actions in } \\
\text { everyday life, such as respect } \\
\text { and respect, tolerance and } \\
\text { selectiveness. }\end{array}$ \\
\hline
\end{tabular}

\begin{tabular}{ll}
\hline Widiyono, & Qualitative \\
S., 2019 & research \\
& methods through \\
& analysis of \\
& literature studies
\end{tabular}

The weakening of nationalism is due to the weakening of patriotism among Generation Z.
The spirit of nationalism is still needed by the existence of the Indonesian nation and state. High nationalism from citizens or the younger generation will make positive and best behaviour for the nation and state.

Youth need to instil an attitude of unity and integrity under the Pancasila ideology as one of the implementations of nationalism awareness.

\begin{tabular}{lll}
\hline Shofa, & The qualitative & The effect of divisive \\
A.M.A, & research method & conflict can reduce the \\
Kodir, A., & is in the form of & nationalism awareness \\
Alfaqi, & direct analysis of & of a young person. \\
M.Z., & youth in Sisir & \\
Subekti, A., & Village, Batu & \\
2019 & District
\end{tabular}

\begin{tabular}{llll}
\hline $\begin{array}{l}\text { Handitya, } \\
\text { B.,2019 }\end{array}$ & $\begin{array}{l}\text { Qualitative } \\
\text { research } \\
\text { methods through } \\
\text { analysis of } \\
\text { literature studies }\end{array}$ & $\begin{array}{l}\text { Education that only } \\
\text { focuses on science and } \\
\text { intelligence. However, } \\
\text { ignoring character } \\
\text { education is the cause } \\
\text { of the degradation of } \\
\text { nationalism. }\end{array}$ & $\begin{array}{l}\text { The younger generation is } \\
\text { taught about superior character } \\
\text { and noble character by } \\
\text { applying the values of } \\
\text { Pancasila and living a moral } \\
\text { life. }\end{array}$ \\
\hline $\begin{array}{l}\text { Murdiono, } \\
\text { M., }\end{array}$ & $\begin{array}{l}\text { Qualitative } \\
\text { research method } \\
\text { through direct } \\
\text { analysis of }\end{array}$ & $\begin{array}{l}\text { Description of } \\
\text { Indonesian youth } \\
\text { nationalism education } \\
\text { generation in the era of } \\
\text { globalization. }\end{array}$ & $\begin{array}{l}\text { The results of the research are } \\
\text { used to foster the younger } \\
\text { generation of nationalism in } \\
\text { schools, either through } \\
\text { teachers or extracurricular }\end{array}$ \\
\hline
\end{tabular}




\begin{tabular}{ll}
\hline school civic & activities. \\
education & \\
teachers in the & \\
Special Region & \\
of Yogyakarta &
\end{tabular}

\begin{tabular}{|c|c|c|c|}
\hline $\begin{array}{l}\text { Rachmawati } \\
\text {, F., } \\
\text { Purwaningr } \\
\text { um, J.P., } \\
2019\end{array}$ & $\begin{array}{l}\text { Qualitative } \\
\text { research } \\
\text { methods }\end{array}$ & $\begin{array}{l}\text { Mathematics can be } \\
\text { used to improve the } \\
\text { character of } \\
\text { nationalism. }\end{array}$ & $\begin{array}{l}\text { Mathematics associated with } \\
\text { Indonesian culture } \\
\text { (Ethnomathematics) can be } \\
\text { done through the discovery } \\
\text { learning model so that students } \\
\text { do not forget their culture and } \\
\text { can develop the character of } \\
\text { nationalism. }\end{array}$ \\
\hline
\end{tabular}

\begin{tabular}{lll}
\hline Mardawani & Qualitative & Nationalism awareness \\
dan & descriptive & is based on national \\
Veronika, & $\begin{array}{l}\text { research method } \\
\text { commitment which can }\end{array}$ \\
L.,2019 & $\begin{array}{l}\text { through data } \\
\text { analysis }\end{array}$ & be interpreted as love \\
& for the nation and state.
\end{tabular}

As the younger generation, the expression of love for the country can be in the form of national insight. The national insight in question is in the form of inward and outward viewing as a nation towards economic, social, cultural ideologies, etc.

\begin{tabular}{lll}
\hline Silva, & Qualitative & The Industrial \\
S.D.F., & research & Revolution 4.0 \\
Glorino, M., & methods through & influenced \\
2021 & literature review & $\begin{array}{l}\text { understanding the } \\
\text { ideology of Pancasila } \\
\end{array}$ \\
& & and its values, \\
& especially nationalism.
\end{tabular}

Natural resources, especially Generation Z \& Millennials, will be superior if they take advantage of the rapid technological advances with the right methods, even though various challenges arise from the negative effects of the Industrial revolution.

\begin{tabular}{llll}
\hline $\begin{array}{l}\text { Putri, H.R., } \\
\text { Metiadini, } \\
\text { A., } \\
\text { Rachmat, } \\
\text { H.K., Iksan, } \\
\text { A., 2020 }\end{array}$ & $\begin{array}{l}\text { The research } \\
\text { literature study }\end{array}$ & $\begin{array}{l}\text { Dispel the spirit of } \\
\text { nationalism among the } \\
\text { youth that threatens the } \\
\text { existence of the } \\
\text { Indonesian nation in the } \\
\text { current era of global } \\
\text { competition. }\end{array}$ & $\begin{array}{l}\text { Threats that will be faced by } \\
\text { the nation are not only military } \\
\text { threats but also non-military } \\
\text { threats, such as eroding the } \\
\text { sense of nationalism of the } \\
\text { millennial generation. That's } \\
\text { the importance of state defence } \\
\text { education. }\end{array}$ \\
\hline $\begin{array}{l}\text { Sakinah, } \\
\text { R.N., Dewi, } \\
\text { D.A., 2021 }\end{array}$ & $\begin{array}{l}\text { The research } \\
\text { literature study }\end{array}$ & $\begin{array}{l}\text { Nationalism awareness } \\
\text { can be increased } \\
\text { through increased } \\
\text { character education. }\end{array}$ & $\begin{array}{l}\text { Character education in the } \\
\text { younger generation can be } \\
\text { based on the values of } \\
\text { Pancasila. This study shows } \\
\text { that nine Pancasila character }\end{array}$ \\
\hline
\end{tabular}




\begin{tabular}{|c|c|c|c|}
\hline & & & $\begin{array}{l}\text { values can be taught to the } \\
\text { younger generation as a form } \\
\text { of increasing awareness of } \\
\text { nationalism. }\end{array}$ \\
\hline $\begin{array}{l}\text { Septania, S., } \\
\text { Proborini, } \\
\text { R., } 2020\end{array}$ & $\begin{array}{l}\text { This study uses } \\
\text { a quantitative } \\
\text { approach with } \\
\text { data collection } \\
\text { tools in the form } \\
\text { of a Likert type } \\
\text { of psychological } \\
\text { scale. }\end{array}$ & $\begin{array}{l}\text { Internet addiction } \\
\text { greatly affects the } \\
\text { participation of } \\
\text { Generation } \mathrm{Z} \text { in public } \\
\text { relations so that it } \\
\text { threatens unity \& } \\
\text { integrity. }\end{array}$ & $\begin{array}{l}\text { Generation } \mathrm{Z} \text { has the potential } \\
\text { to experience internet } \\
\text { addiction, which can cause } \\
\text { various adverse effects for } \\
\text { themselves and their social } \\
\text { life. Self-compassion \& grit } \\
\text { are needed to stem the bad } \\
\text { effects of this internet } \\
\text { addiction. }\end{array}$ \\
\hline $\begin{array}{l}\text { Arliman, } \\
\text { L.,2020 }\end{array}$ & $\begin{array}{l}\text { Qualitative } \\
\text { research } \\
\text { methods are } \\
\text { descriptive- } \\
\text { analytical }\end{array}$ & $\begin{array}{l}\text { Civic education has an } \\
\text { important role in the } \\
\text { formation of a sense } \\
\text { and awareness of } \\
\text { nationalism. }\end{array}$ & $\begin{array}{l}\text { Civic education is made to be } \\
\text { flexible according to the needs } \\
\text { of citizens in the era of } \\
\text { digitalization. In addition, it } \\
\text { would be better if an } \\
\text { introduction was made to the } \\
\text { rights and obligations as } \\
\text { citizens. }\end{array}$ \\
\hline $\begin{array}{l}\text { Hayati, } \\
\text { S.F.N., } \\
\text { Pandin, } \\
\text { M.G.R., } \\
2021\end{array}$ & $\begin{array}{l}\text { This is a } \\
\text { qualitative study } \\
\text { through a } \\
\text { literature review } \\
\text { taken from } \\
\text { Google Scholar }\end{array}$ & $\begin{array}{l}\text { The Covid-19 pandemic } \\
\text { indirectly has a bad } \\
\text { influence on the sense } \\
\text { of nationalism in } \\
\text { Indonesia, which also } \\
\text { has an impact on } \\
\text { people's psychology. }\end{array}$ & $\begin{array}{l}\text { The government needs to help } \\
\text { the community in generating a } \\
\text { sense of nationalism in the } \\
\text { pandemic era. Bhineka } \\
\text { Tunggal Ika is also one of the } \\
\text { keys to uniting the differences } \\
\text { that exist in society. }\end{array}$ \\
\hline $\begin{array}{l}\text { Sebayang, } \\
\text { E.R.B., } \\
2019\end{array}$ & $\begin{array}{l}\text { Qualitative } \\
\text { research } \\
\text { methods through } \\
\text { analysis of } \\
\text { literature studies }\end{array}$ & $\begin{array}{l}\text { There are negative and } \\
\text { positive influences } \\
\text { about nationalism in } \\
\text { this digital era on the } \\
\text { millennial generation. }\end{array}$ & $\begin{array}{l}\text { Many things can be done such } \\
\text { as developing nationalism, } \\
\text { maintaining their own culture, } \\
\text { and respecting the existing } \\
\text { cultural diversity. }\end{array}$ \\
\hline $\begin{array}{l}\text { Marsono, } \\
\text { M., } 2019\end{array}$ & $\begin{array}{l}\text { Qualitative } \\
\text { method }\end{array}$ & $\begin{array}{l}\text { The fading of the } \\
\text { typical values of the } \\
\text { Indonesian nation's } \\
\text { character and culture } \\
\text { can be an inhibiting } \\
\text { factor in the global era. }\end{array}$ & $\begin{array}{l}\text { Awareness of nationalism and } \\
\text { problems in Indonesia can be } \\
\text { overcome through the } \\
\text { provision of character } \\
\text { education based on cultural } \\
\text { values to the younger } \\
\text { generation. }\end{array}$ \\
\hline $\begin{array}{l}\text { Pratiwi, } \\
\text { J.W., } \\
\text { Pujiastuti, } \\
\text { H., } 2020 .\end{array}$ & $\begin{array}{l}\text { Qualitative } \\
\text { research } \\
\text { methods through } \\
\text { ethnographic }\end{array}$ & $\begin{array}{l}\text { The application of } \\
\text { ethnomathematics in } \\
\text { fostering a sense of love } \\
\text { for culture through the }\end{array}$ & $\begin{array}{l}\text { Through ethnomathematics, } \\
\text { the love of culture \& love for } \\
\text { the homeland of Generation } \mathrm{Z} \\
\text { can be rooted in them so that }\end{array}$ \\
\hline
\end{tabular}




\begin{tabular}{|c|c|c|c|}
\hline & $\begin{array}{l}\text { methods } \\
\text { (observations } \\
\text { through } \\
\text { documentation, } \\
\text { interviews, and } \\
\text { literature } \\
\text { studies) }\end{array}$ & game of marbles. & $\begin{array}{l}\text { the character of nationalism } \\
\text { remains strong. }\end{array}$ \\
\hline $\begin{array}{l}\text { Ulaan, G.F., } \\
\text { Lusiana, } \\
\text { N.A., } \\
\text { Wahyudi, } \\
\text { K.E.,2020 }\end{array}$ & $\begin{array}{l}\text { Qualitative } \\
\text { descriptive } \\
\text { research method } \\
\text { with data in the } \\
\text { form of } \\
\text { interviews }\end{array}$ & $\begin{array}{l}\text { The political, social, } \\
\text { and economic } \\
\text { environment among } \\
\text { students as the younger } \\
\text { generation can be an } \\
\text { important factor in the } \\
\text { realization of } \\
\text { nationalism awareness. }\end{array}$ & $\begin{array}{l}\text { Awareness of nationalism in } \\
\text { students can be maintained by } \\
\text { participating in various } \\
\text { institutions at the University, } \\
\text { one of which is the Student } \\
\text { Activity Unit }\end{array}$ \\
\hline $\begin{array}{l}\text { Pratiwi, A., } \\
\text { Asyarotin, } \\
\text { E.N.K, } \\
2019\end{array}$ & $\begin{array}{l}\text { Literature study } \\
\text { method with a } \\
\text { descriptive } \\
\text { qualitative } \\
\text { approach }\end{array}$ & $\begin{array}{l}\text { The phenomenon of } \\
\text { disinformation that } \\
\text { occurs in the millennial } \\
\text { generation is closely } \\
\text { related to conflict, } \\
\text { which can fade the } \\
\text { sense of nationalism. }\end{array}$ & $\begin{array}{l}\text { Cultural literacy \& awareness } \\
\text { of the millennial generation is } \\
\text { the key to minimizing the } \\
\text { impact of disinformation so } \\
\text { that conflicts do not easily } \\
\text { occur. }\end{array}$ \\
\hline $\begin{array}{l}\text { Kartini, A., } \\
\text { Dewi, D.A., } \\
2021\end{array}$ & $\begin{array}{l}\text { A qualitative } \\
\text { method through } \\
\text { literature study, } \\
\text { by reviewing } \\
\text { various related } \\
\text { sources }\end{array}$ & $\begin{array}{l}\text { In the era of } \\
\text { digitalization, the role } \\
\text { of Pancasila education } \\
\text { is very much needed in } \\
\text { building a sense of } \\
\text { nationalism for the } \\
\text { younger generation }\end{array}$ & $\begin{array}{l}\text { Generation } \mathrm{Z} \text {, through } \\
\text { mastering technology and } \\
\text { Pancasila education, should be } \\
\text { able to implement the values of } \\
\text { Pancasila, so that a sense of } \\
\text { nationalism can grow }\end{array}$ \\
\hline $\begin{array}{l}\text { Sultoni, S., } \\
\text { Gunawan, } \\
\text { I., } \\
\text { Argadinata, } \\
\text { H., } 2020\end{array}$ & $\begin{array}{l}\text { Quantitative- } \\
\text { causality method }\end{array}$ & $\begin{array}{l}\text { The lack of character } \\
\text { learning in this digital } \\
\text { era }\end{array}$ & $\begin{array}{l}\text { With this research, it seeks to } \\
\text { link student character learning } \\
\text { in the digital era }\end{array}$ \\
\hline $\begin{array}{l}\text { Anggraini, } \\
\text { D., Fathari, } \\
\text { F., Anggara, } \\
\text { J.W., Amin, } \\
\text { M.D.A.A., } \\
2020\end{array}$ & $\begin{array}{l}\text { The method } \\
\text { used is the } \\
\text { method } \\
\text { literature study, } \\
\text { where data } \\
\text { collection } \\
\text { techniques by } \\
\text { conducting a } \\
\text { study } \\
\text { to books- } \\
\text { books, literature, }\end{array}$ & $\begin{array}{l}\text { Starting to lose the } \\
\text { appreciation of the } \\
\text { Pancasila values for the } \\
\text { millennial generation }\end{array}$ & $\begin{array}{l}\text { Because the millennial } \\
\text { generation has shifted the way } \\
\text { of life from Pancasila, this } \\
\text { research is useful for re- } \\
\text { applying the values contained } \\
\text { in Pancasila in this millennial } \\
\text { life }\end{array}$ \\
\hline
\end{tabular}




\begin{tabular}{|c|c|c|c|}
\hline & $\begin{array}{l}\text { notes, journals } \\
\text { that are related } \\
\text { to the problem } \\
\text { discussed }\end{array}$ & & \\
\hline $\begin{array}{l}\text { Sari, S., } \\
2019\end{array}$ & $\begin{array}{l}\text { Qualitative- } \\
\text { The inductive } \\
\text { research method } \\
\text { that focuses on } \\
\text { literature review }\end{array}$ & $\begin{array}{l}\text { Lack of ability to use } \\
\text { technology and filter } \\
\text { information }\end{array}$ & $\begin{array}{l}\text { Regarding digital } \\
\text { developments that continue to } \\
\text { grow rapidly, media literacy } \\
\text { skills in the digital era are } \\
\text { needed to avoid } \\
\text { misinformation }\end{array}$ \\
\hline $\begin{array}{l}\text { Widiyaning } \\
\text { rum, W.Y., } \\
2019\end{array}$ & $\begin{array}{l}\text { Research in the } \\
\text { form of } \\
\text { theoretical } \\
\text { studies }\end{array}$ & $\begin{array}{l}\text { The value of the } \\
\text { younger generation's } \\
\text { awareness of Pancasila } \\
\text { is still often } \\
\text { misunderstood, even } \\
\text { though a sense of } \\
\text { nationalism is very } \\
\text { much needed in } \\
\text { building a better } \\
\text { Indonesia }\end{array}$ & $\begin{array}{l}\text { Pancasila must be upheld by } \\
\text { Generation Z because } \\
\text { Pancasila is very important in } \\
\text { maintaining the existence of } \\
\text { the nation's personality, } \\
\text { especially in the era of rapid } \\
\text { globalization }\end{array}$ \\
\hline $\begin{array}{l}\text { Zidniyati, } \\
2019\end{array}$ & $\begin{array}{l}\text { Research using } \\
\text { literature study }\end{array}$ & $\begin{array}{l}\text { Moral education is } \\
\text { important because } \\
\text { morality is one of the } \\
\text { identities of the } \\
\text { Indonesian nation }\end{array}$ & $\begin{array}{l}\text { Instilling values and morality, } \\
\text { creating a model for teaching } \\
\text { moral values, and facilitating } \\
\text { values and morality according } \\
\text { to the abilities of the younger } \\
\text { generation }\end{array}$ \\
\hline $\begin{array}{l}\text { Rahayu, H., } \\
2021\end{array}$ & $\begin{array}{l}\text { Qualitative } \\
\text { research method } \\
\text { with a case } \\
\text { study approach }\end{array}$ & $\begin{array}{l}\text { Blended learning has } \\
\text { the potential to have a } \\
\text { more effective impact } \\
\text { in instilling an attitude } \\
\text { of nationalism in } \\
\text { students during a } \\
\text { pandemic }\end{array}$ & $\begin{array}{l}\text { Teaching methods must adapt } \\
\text { from conventional to digital } \\
\text { because it is very useful in the } \\
\text { effective delivery of } \\
\text { knowledge, including the } \\
\text { values of nationalism }\end{array}$ \\
\hline $\begin{array}{l}\text { Atika, N.T., } \\
\text { Wakhuyudi } \\
\text { n, H., } \\
\text { Fajriyah, } \\
\text { K.,2019 }\end{array}$ & $\begin{array}{l}\text { A qualitative } \\
\text { method with a } \\
\text { descriptive } \\
\text { approach }\end{array}$ & $\begin{array}{l}\text { The love for the } \\
\text { homeland has decreased } \\
\text { along with the moral } \\
\text { decline caused by the } \\
\text { use of gadgets }\end{array}$ & $\begin{array}{l}\text { The formation of the character } \\
\text { of love for the land can be } \\
\text { done through Strengthening } \\
\text { Character Education for the } \\
\text { younger generation }\end{array}$ \\
\hline $\begin{array}{l}\text { Wijaya, } \\
\text { A.G., } \\
\text { Suliwanings } \\
\text { ih, Pritama, }\end{array}$ & $\begin{array}{l}\text { Research } \\
\text { method through } \\
\text { literature study }\end{array}$ & $\begin{array}{l}\text { There are significant } \\
\text { opportunities that can } \\
\text { improve educational } \\
\text { tools and nationalism }\end{array}$ & $\begin{array}{l}\text { Can increase the sense of } \\
\text { nationalism and improve } \\
\text { educational tools through } \\
\text { game-based learning media, }\end{array}$ \\
\hline
\end{tabular}


Timothy Adamentha Tarigan, Fredrick Liui, Muhammad Hanif, Moses Glorino Rumambo Pandin

\begin{tabular}{llll}
\hline A.D., 2019 & & & $\begin{array}{l}\text { and games provide new } \\
\text { instructions and perspectives }\end{array}$ \\
\hline $\begin{array}{l}\text { Asyari, D., } \\
\text { Dewi, D.A., }\end{array}$ & $\begin{array}{l}\text { Online Research } \\
\text { Method (ORM) } \\
\text { researchers } \\
\text { collect data via } \\
\text { the internet }\end{array}$ & $\begin{array}{l}\text { The development of } \\
\text { science and technology } \\
\text { is increasingly modern, } \\
\text { demanding morality and } \\
\text { a high level of } \\
\text { nationalism }\end{array}$ & $\begin{array}{l}\text { With citizenship education, it } \\
\text { can touch the realm of student } \\
\text { awareness }\end{array}$ \\
\hline $\begin{array}{l}\text { Sholihatin, } \\
\begin{array}{l}\text { E., } \\
\text { Kusnarto, } \\
\text { Warsiman. }\end{array}\end{array}$ & $\begin{array}{l}\text { Qualitative } \\
\text { method }\end{array}$ & $\begin{array}{l}\text { The value of local } \\
\text { wisdom and state } \\
\text { defence is one of the } \\
\text { factors in increasing } \\
\text { nationalism }\end{array}$ & $\begin{array}{l}\text { Harmonization between local } \\
\text { wisdom and state defence is } \\
\text { manifested in attitudes, such as } \\
\text { solidarity, tolerance, harmony, } \\
\text { and mutual cooperation }\end{array}$ \\
\end{tabular}

\section{Discussion}

Just like other generations, Generation $\mathrm{Z}$ also has its characteristics. Unfortunately, some of those characteristics could be "an exclamation mark" for Indonesian national identity. Generation $\mathrm{Z}$ is an ambitious and competitive generation. This causes Generation $\mathrm{Z}$ to always be motivated to try various ways to improve their abilities. Sadly, this could sometimes lead to anxiety \& depression towards the competition they face. The word "FOMO" is also frequently linked to Generation Z. FOMO, or short for Fear of Missing Out, is the fear of being "left behind" due to not participating in a certain activity or moment. Their passion will waver if they fail to achieve something.

Generation $\mathrm{Z}$ is a generation most exposed to developments in information technology. That's why they are adaptable \& become familiar with the technology. This advancement became a threat for Generation Z, especially in this pandemic where Indonesia \& the world were forced to the advancement of the digital era. The rapid development of technology \& the digital era is also closely related to the use of smartphones and the internet, and both of them could be very addictive for Generation $\mathrm{Z}$. Generation $\mathrm{Z}$ is the most vulnerable to internet addiction, and this could lower their social participation due to them too fixated on the virtual world. Not only that, the easiness of gathering information creates a "harmful smartphone" if it is misused for negative purposes such as pornography, which will affect the decline of moral values in the young generation. Based on that example, moral degradation is also one of the real forms of the decline in an individual's nationalism.

On the other hand, challenges of nationalism appear along with globalization through foreign cultures. Along with the entry of western cultures, the spirit of Indonesian nationalism is gradually fading, especially among the young generation. Nowadays, more young generations are losing their sense of nationalism. The additional problem also comes from the rapidness of development in the digitalization era. Currently, we are facing the dilemma of original Indonesian culture's displacement due to the global cultural forces from outsiders that led to negative acculturation which unites bad elements of other cultures with our nation's culture. Technology nowadays gives the freedom of speech to Generation Z, which affects their attitude \& behaviour. Freely-accessed information and its vast circulation enable irresponsible people to make and share provocative digital content, such as hoaxes and hate speech. Both of them are examples that are frequently found in social media. Hate speech could be leading to insecurity \& inconveniences feelings to other societies, and could even cause material loss for 
certain people or society in general, damaging public facilities for example. For hoaxes, it could influence others to believe information full of negativity. Hate speech \& hoax are examples of disinformation phenomena, and contradictory \& conspiratorial technological development which has made the disinformation phenomenon more flourished and predicting paradigm \& moral values of the modern generation became even harder. This could potentially break the union and weaken the nationalism spirit, especially for Generation Z.

Not only that, the waning spirit of young generation nationalism, including Gen Z, also comes from people's attitudes towards the environment around them. The environment of Generation Z children is currently dominated by the virtual world, which seems to be their "new friend". Children's characters become more dynamic, but more prone to collapse if not properly supervised. This will certainly be a threat to the moral \& spirit of nationalism of young people. Let alone the virtual world, even the simplest things, such as upbringing from the family, can also affect the loss of the spirit of nationalism of the younger generation.

The problems which are explained above can be overcome by instilling a national commitment based on Pancasila. Pancasila is the ideology of Indonesia that was born from the culture and history of the Indonesian people and it existed long before Indonesia became an independent nation. Inside the ideology of Pancasila, there are noble values that become a foundation for the moral attitudes and behaviour of the Indonesian people. In the values of Pancasila, there are points of life such as religious, obedience, humanity, civilized and ethical living, cooperation, tolerance, sympathy, empathy, and wisdom. In addition, there are nine characteristics of Pancasila's value that need to be taught to the younger generation, such as love God, trust, reverence, loyalty; responsibility, excellence, self-reliance, discipline, orderliness; trustworthiness, reliability, honesty; respect, courtesy, obedience; love, compassion, caring, empathy, generosity, moderation, cooperation; confidence, assertiveness, creativity, resourcefulness, courage, determination and enthusiasm; justice, fairness, mercy, leadership; kindness, friendliness, humility, modesty and tolerance, flexibility, peacefulness, unity. Those Characteristics and noble values can be given to Generation $\mathrm{Z}$ through character education in various educational institutions. Further implementation is carried out by realizing the noble values of the nation in real life.

Character education that can help Generation $\mathrm{Z}$ face the challenges of nationalism needs to fulfil 3 important aspects. First, character education focuses on teaching values which in learning prioritize the introduction of local wisdom academically. Second, character education focuses on clarifying values in which teachers must be able to explain which ones are good \& bad when socializing in society. Third, character education focuses on a character development approach where collaboration between teachers and parents becomes very important at this point. Each important aspect that has been mentioned has its priority. The first aspect focuses on intellectual, scientific, and understanding. The second aspect focuses on habits. The last aspect focuses on the moral development of an individual. From these three aspects, in general, character development in Generation $\mathrm{Z}$ should aim at developing moral character through the habit of mutual respect and motivation.

Character education can be provided through three important areas around Generation $\mathrm{Z}$, such as family, school, and community. To solve the problem of decreasing awareness of nationalism, elements of cultural and civic education, such as national identity, nationality and citizenship, rights and obligations of citizens, democracy and Indonesian civil society, insight into the archipelago, and human rights need to be conveyed in the provision of character education. The delivery model of civic education should be done in two ways. First, through direct citizenship education, such as providing learning materials and assignments. Both models are delivered using extracurricular. Giving the concept of citizenship through extracurricular can increase the nationalism of the younger generation. The younger generation can be encouraged to become moral agents in society that reflect behaviour under national identity. 
When all components of character education are met, the phenomenon of disinformation will fade and moral values and nationalist character can be well maintained.

Innovative solutions and unique approaches are needed to overcome this nationalism sense problem in Generation Z. One of them is ethnomathematics. Ethnomathematics is a mathematics concept combined with culture. Both of them have indirect linkages. Nationalism's character could be implemented in the form of efforts to preserve Indonesian culture. The fusion of Indonesian cultures and mathematics which also require literation \& reasoning skills is pretty much possible. Ethnomathematics is also very possible to be applied to learning in schools because it can support the discovery learning method, which is when students could build their knowledge through concept findings, which become one of the important concepts in revolutionizing Indonesian education. One of the ways to implement ethnomathematics is from Indonesian traditional games, such as marble game, and many more. With ethnomathematics, young generations, especially Generation Z, could cultivate a sense of love for their cultures \& their homeland so nationalism is expected to be strengthened in them.

Scout extracurricular could also be another alternative solution. Scout values, reflected by the Scout's Dasa Dharma, are a form of character education for Generation Z. Through these Dasa Dharma values, Generation $\mathrm{Z}$ can improve their morality and attitude of nationalism. Scouts certainly need to be more attractive for the young generation so they don't hesitate to participate in the activities. Interesting activities that could be done through scout extracurricular are camping and jamboree.

\section{Conclusion}

Based on the literature study and qualitative research that we have done about challenges and solutions which are faced by Indonesia Generation Z in maintaining nationalism, we conclude that generally the challenges can be caused by bad characteristics of Generation $\mathrm{Z}$, misuse of technological advances, foreign cultures (western cultures), and social media as well as the virtual world. Those problems can be overcome by solutions such as Pancasila and character education. Pancasila as a national foundation holds noble values that become a foundation for the moral attitudes and behaviour of the Indonesian people. Pancasila also became an Indonesian ideology that can represent the identity of Indonesia. Furthermore, another solution can be implemented by character education which is given to Generation $\mathrm{Z}$. Character education can be provided through three important areas around Generation Z, such as family, school, and community.

In Indonesia, the implementation of solutions can be seen in the form of ethnomathematics and scout. Ethnomathematics is a mathematics concept combined with culture. These concepts give Generation $\mathrm{Z}$ an important value to embrace their own cultures through literature and math. On the other hand, there is a scout that also helps Generation $\mathrm{Z}$ to construct their moral values based on Dasa Dharma. Those solutions can help Generation $\mathrm{Z}$ to maintain its nationalism in the digital era. 


\section{BIBLIOGRAFI}

Anggraini, D., Fathari, F., Anggara, J.W., Amin, M.D.A.A. (2020). Pengamalan Nilai-Nilai Pancasila Bagi Generasi Milenial. Jurnal Inovasi Ilmu Sosial dan Politik, 2(1), 11-18. Google Scholar

Arliman, L. (2020). Tantangan Pendidikan Kewarganegaraan pada Revolusi 4.0. Ensiklopedia Social Review, 2(3), 333-339. Google Scholar

Asyari, D., Dewi, D.A. (2021). Peran Pendidikan Kewarganegaraan bagi Generasi Milenial dalam Menanamkan Jiwa Nasionalisme Di Era Globalisasi. Jurnal Universitas Pahlawan, 3(2), 30-41. Google Scholar

Atika, N.T., Wakhuyudin,H., Fajriyah, K. (2019). Pelaksanaan Penguatan Pendidikan Karakter Membentuk Karakter Cinta Tanah Air. Jurnal Mimbar Ilmu, 24(1), 105-113. Google Scholar

Degtyareva, V. V, Sozaeva, D. A., \& Dong, Z. (2021). The Era of Digitalization: Philosophical, Social, and Managerial Factors. In E. G. Popkova, V. N. Ostrovskaya, \& A. V Bogoviz (Eds.), Socio-economic Systems: Paradigms for the Future (pp. 1691-1700). Springer International Publishing. Google Scholar

Handitya, B. (2019). Menyemai Nilai Pancasila Pada Generasi Muda Cendekia. ADIL Indonesia Journal, 2(1), 13-23. Google Scholar

Hermino, A., Arifin, I. (2020). Contextual character education for students in senior high school. European Journal of Educational Research, 9(3), 1009-1023. 10.12973/eujer.9.3.1009 Google Scholar

Jensen. (2016). The Roots of Nationalism: National Identity Formation in Early Modern Europe, 1600-1815. Amsterdam University Press Google Scholar

Kartini, A., Dewi, D.A. (2021). Implementasi Pendidikan Pancasila Dalam Menumbuhkan Rasa Nasionalisme Generasi Muda di Era Digital. Jurnal Pendidikan dan Kewirausahaan, 9(1), 405-418. Google Scholar

Lestari, E.Y., Janah, M., Wardani, P.K. (2019). Menumbuhkan Kesadaran Nasionalisme Generasi Muda di Era Globalisasi Melalui Penerapan Nilai-Nilai Pancasila. ADIL Indonesia Journal, 1(1), 20-27. Google Scholar

Mardawani, L.V. (2019). Implementasi Nilai Luhur Pancasila Melalui Kegiatan Bakti Mahasiswa untuk Memperkuat Komitmen Kebangsaan pada Generasi Milenial. Jurnal PEKAN, 4(2), 134-148. Google Scholar

Marsono, M. (2019). Pendidikan Karakter Berbasis Nilai Budaya di Era Milenial. Prosiding Seminar Nasional Dharma Acarya, 1(1), 51-58. Google Scholar

Murdiono, M., Wuryandani, W. (2021). Civic and nationalism education for young Indonesian generation in the globalization era. Jurnal Civics: Media Kajian Kewarganegaraan, 18(1), 158-171. Google Scholar

Pratiwi, A., Asyarotin, E.N.K. (2019). Implementasi literasi budaya dan kewargaan sebagai solusi disinformasi pada generasi millennial di Indonesia. Jurnal Kajian Informasi \& Perpustakaan, 7(1), 65-80. Google Scholar

Pratiwi, J.W., Pujiastuti, H. (2020). Eksplorasi Etnomatematika Pada Permainan Tradisional Kelereng. Jurnal Pendidikan Matematika Raflesia, 5(2), 1-12. Google Scholar

Putri, H.R., Metiadini, A., Rahmat, H.K., Uksan, A. (2020). Urgensi Pendidikan Bela Negara Guna Membangun Sikap Nasionalisme Pada Generasi Millenial di Indonesia. AlMuaddib: Jurnal Ilmu-Ilmu Sosial dan Keislaman, 5(2), 257-271. Google Scholar

Rachmawati, F., Purwaningrum, J.P. (2019). Model Discovery Learning Berbasis Etnomatematika pada Bangun Ruang untuk Menumbuhkan Kemampuan Literasi dan Karakter Nasionalisme pada Generasi Z 4.0. AKSIOMA: Jurnal Matematika dan Pendidikan Matematika, 10(2), 254-260. Google Scholar 
Timothy Adamentha Tarigan, Fredrick Liui, Muhammad Hanif, Moses Glorino Rumambo Pandin

Rahayu, H. (2021). Penerapan Model Pembelajaran Blended Learning Pada Pendidikan Kewarganegaraan Dalam Menanamkan Sikap Nasionalisme Peserta Didik di Era Society 5.0 (Studi Kasus di SMP Negeri 36 Bandung). Seminar Nasional Pendidikan, 3(0), 1-7. Google Scholar

Sakinah, R.N, Dewi, D.A. (2021). Implementasi Nilai-Nilai Pancasila sebagai Karakter Dasar Para Generasi Muda dalam Menghadapi Era Revolusi Industrial 4.0. Jurnal Kewarganegaraan, 5(1), 152-167. Google Scholar

Sari, S. (2019). Literasi Media Pada Generasi Milenial di Era Digital. Jurnal Professional FIS UNIVED, 6(2), 30-42. Google Scholar

Septania, S., Proborini, R. (2020). Self-Compassion, Grit dan Adiksi Internet pada Generasi Z. Jurnal Magister Psikologi UMA, 12(2), 138-147. Google Scholar

Shofa, A.M.A., Kodir, A., Alfaqi, M.Z., Subekti,A. (2019). Wanua Nusantara: Praktik Pembumian Nilai-Nilai Pancasila di Kalangan Generasi Muda. Jurnal Praksis dan Dedikasi Sosial, 2(1), 1-5. Google Scholar

Sholihatin, E., Kusnarto, Warsiman. (2020). Harmonisasi Nilai-Nilai Bela Negara Dengan Sistem Nilai Kearifan Lokal Masyarakat Untuk Meningkatkan Nasionalisme. Public Administration Journal of Research, 2(2), 139-151. Google Scholar

Sultoni, S., Gunawan, I., Argadinata, H. (2020). Dampak Pembelajaran berkarakter terhadap Penguatan Karakter Siswa Generasi Milenial. JAMP: Jurnal Administrasi dan Manajemen Pendidikan, 3(2), 160-170. Google Scholar

Tuckman, B.W. \& Harper, B.E. (2012). Conducting Educational Research. Rowman \& Littlefield Publisher Google Scholar

Ulaan, F.G., Lusiana, N.A., Wahyudi, K.E. (2020). Implementasi Nilai Kesadaran Berbangsa dan Bernegara di Unit Kegiatan Mahasiswa. Jurnal Syntax Idea, 2(6), 56-71. Google Scholar

Widiyaningrum, W.Y. (2019). Menumbuhkan Nilai Kesadaran Pancasila di Kalangan Generasi Muda. Kajian Teoritis. Jurnal JISIPOL, 3(3), 69-79. Google Scholar

Widiyono, S. (2019). Pengembangan Nasionalisme Generasi Muda di Era Globalisasi. Jurnal Populika, 7(1), 12-21. Google Scholar

Wijaya, A.G., Suliwaningsih, Pritama, A.D. (2019). Meningkatkan Rasa Nasionalisme Siswa Melalui Game Base Learning. Jurnal MATRIK, 19(1), 196-204. Google Scholar

Zidniyati. (2019). Penguatan Pendidikan Karakter di Sekolah Dasar di Era Revolusi Industri 4.0. Jurnal TARBIYATUNA, 3(1), 41-58. Google Scholar

\section{First publication right:}

Jurnal Syntax Fusion: Jurnal Nasional Indonesia

\section{This article is licensed under:}

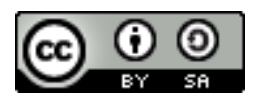

